\title{
In Vitro Antibacterial Effect of the Combination of Galla rhois ethanol extracts and Sodium chlorate against Intramacrophage Brucella abortus
}

\author{
Chun-Nam Cha ${ }^{1 \dagger}$, II-Hwa Hong ${ }^{2 \dagger}$, Eun-Ah Yu ${ }^{3}$, Eun-Kee Park', Chang-Yeol Yoo ${ }^{5}$, Suk Kim², and Hu Jang Lee ${ }^{2 *}$ \\ ${ }^{1}$ Engineering Research Institute, Department of Industrial Systems Engineering, \\ Gyeongsang National University, Chinju 600-701, Korea \\ ${ }^{2}$ Gyeongsang Research Institute of Life Sciences, College of Veterinary Medicine, \\ Gyeongsang National University, Chinju 600-701, Korea \\ ${ }^{3}$ Tongyeong National Quarantine Station, Ministry of Health \& Welfare, Tongyeong 650-110, Korea \\ ${ }^{4}$ Medical Humanities and Social Medicine, College of Medicine, Kosin University, Busan 602-703, Korea \\ ${ }^{5}$ Department of Computer Information, Gyeongnam Provincial Namhae College, Namhae 668-801, Korea \\ (Received February 17, 2014/Revised March 4, 2014/Accepted March 8, 2014)
}

\begin{abstract}
This study investigated the antibacterial effects of GR ethanol extracts (GRE), sodium chlorate (SC) and a combination of GRE and SC (GS) on Brucella abortus (B. abortus). The antibacterial activities of GRE, SC and GS towards B. abortus were evaluated by incubating B. abortus with GRE, SC and GS. Following treatment with GRE, SC and GS, B. abortus survival and intracellular proliferation in macrophages were monitored. In the cellular cytotoxicity assay, GRE, SC and GS are not cytotoxic at concentrations less than $400 \mu \mathrm{g} / \mathrm{ml}, 15 \mathrm{mM}$ and $0.6 \mathrm{GS}$ ( 1 of GS, GRE $1,000 \mu \mathrm{g} / \mathrm{ml}+$ SC $30 \mathrm{mM}$ ), respectively. The viability of $B$. abortus was markedly decreased in a dosedependent manner in all treatment groups. In addition, B. abortus intracellular proliferation within macrophages was significantly reduced in cells treated with GRE $(400 \mu \mathrm{g} / \mathrm{mL}), \mathrm{SC}(15 \mathrm{mM})$ and $0.5 \mathrm{GS}(\mathrm{GRE} 500 \mu \mathrm{g} / \mathrm{mL}+\mathrm{SC} 15 \mathrm{mM})$ after $48 \mathrm{hr}$-incubation (GRE, $p<0.01$; $\mathrm{SC}$ and $0.5 \mathrm{GS}, p<0.001$ ). Especially, in the treatment of GS, the synergistic effect of GRE and SC treatment on B. abortus in macrophage was observed. In conclusion, GS is useful as an antibacterial candidate against B. abortus, and can be applied in the field of meat and milk hygiene.
\end{abstract}

Key words : Brucella abortus, Galla rhois, sodium chlorate, the combination of GS and SC

\section{Introduction}

Brucellosis is one of the world's most common zoonotic diseases and is responsible for economic losses in livestock industries ${ }^{1)}$. In addition, the disease represents a considerable and increasing public health burden ${ }^{2,3)}$. Approximately, 500,000 cases of human brucellosis globally are reported to the World Health Organization annually $(\mathrm{WHO})^{4)}$. This zoonotic disease is caused by various species of Brucella that infect many domestic animals, which can act as reservoirs for other animal species and human infection ${ }^{5)}$. The disease is a highly contagious zoonosis caused by ingestion of unsterilized milk and dairy products or meat from infected animals or close contact with their secretions ${ }^{6,7)}$.

Brucellosis is caused by Brucella spp., which are $B$.

\footnotetext{
The first two authors contributed equally to this study

*Correspondence to: Hu-Jang Lee, College of Veterinary Medicine, Gyeongsang National University, 900 Gajwa-dong, Chinju 660-701, Korea

Tel: 82-55-751-6642, Fax: 82-55-751-5803

E-mail: hujang@gnu.ac.kr
}

melitensis, B. abortus, B. suis, B. canis, B. neotomae and B. ovis, and recently the recognized new species have been Brucella ceti, Brucella pinnipedialis, Brucella microti and Brucella inopinata, that contribute to abortion and infertility in various mammals, and well-known undulant fever in humans ${ }^{4,8,9)}$. These bacteria invade and replicate within professional phagocytes such as macrophages and nonprofessional phagocytes such as epithelial cells ${ }^{8,9)}$.

Even today, treatment of brucellosis in human is largely based on the principles applied half a century ago, and few modifications have been made in the following years, despite the emergence of new antibiotic classes and different therapeutic approaches ${ }^{10)}$. As current recommended regimens for brucellosis treatment involve the use of several antibiotics to avoid relapses occurring and to prevent the prolonged use of these drugs, the combined antibiotics use may lead to problems of drug resistance arising and the vital effects with respect to health and safety ${ }^{11,12)}$. However, the alternatives for the brucellosis treatments have not been thoroughly surveyed yet. Thus, the research for alternative treatments of brucellosis is demanded.

Conventional herbal medicines have been used as remedies 
against infectious diseases in Asian countries long ago. Galla rhois (GR) has long been used in traditional Asian medicine to treat diarrhea, persistent coughing and spontaneous perspiration in man due to the antidiarrhetic, astringent and hemostatic properties of this product ${ }^{8,13,14)}$. GR is a harmless natural material that contains a number of tanninderived components, including methyl gallate and gallic $\operatorname{acid}^{15)}$. Especially, the gallotannins are a class of hydrolysable tannin polymers that are formed from gallic acid, which seems to have anti-bacterial, anti-fungal, and anti-viral properties $^{16,17)}$. In the previous study ${ }^{8)}$, GR ethanol extracts (GRE) exhibited antibacterial and protective activities on Brucella abortus (B. abortus) in vitro and in vivo.

Sodium chlorate (SC) is used as an oxidising agent and for making chlorine dioxide used in water disinfection. Chlorate is found as a stable by-product in drinking water that has been disinfected with chlorine dioxide ${ }^{18}$. Previous studies had been carried out on the prevention and treatment of Enterobacteriaceae infections in animals using $\mathrm{SC}^{19,20)} \cdot B$. abortus such as Escherichia coli and Salmonella species has a respiratory nitrate reductase enzyme, which coincidentally catalyses the intracellular reduction of chlorate to chlorite, a cytotoxic product that kills the bacterium in tissue cell $\mathrm{s}^{21,22)}$. As most of the normal anaerobic gut bacteria lack respiratory nitrate reductase activity, chlorate selectively targets bacteria expressing respiratory nitrate reductase activity but not beneficial anaerobes lacking that enzyme ${ }^{19,20)}$.

In the present study, GRE, SC and the combination of GRE and SC (GS) were investigated the antibacterial effect and inhibition of intracellular proliferation on B. abortus.

\section{Materials and Methods}

\section{Cells and culture conditions}

The murine macrophage cell line, RAW 264.7, was obtained from the American Type Culture Collection (ATCC, Rockville, USA) and grown at $37^{\circ} \mathrm{C}$ in a $5 \% \mathrm{CO}_{2}$ atmosphere in RPMI 1640 (hyclone, USA), containing 10\% heatinactivated fetal bovine serum (FBS). The cells were seeded $\left(1 \times 10^{4}\right.$ per well $)$ in cell culture plates and incubated for 24 $\mathrm{hr}$ before infection for all the assays. Prior to the bacterial infection, the cells were washed three times with a sterile phosphate-buffered saline solution (PBS, pH 7.4) to eliminate antibiotics; this step was followed by the addition of fresh culture media (RPMI 1640 medium containing 10\% fetal bovine serum (FBS)) without antibiotics.

\section{Bacterial culture}

B. abortus strains were derived from 544 (ATCC 23448), smooth, virulent $B$. abortus biovar strains, which were obtained from Animal and Plant Quarantine Agency (Anyang,
Korea). B. abortus was maintained as frozen glycerol stocks and cultured in Brucella broth (Becton Dickinson, Sparks, MD.) without antibiotics for 3 days at $37^{\circ} \mathrm{C}$. Bacteria were grown at $37^{\circ} \mathrm{C}$ with vigorous shaking until they reached the stationary phase, and bacterial growth rates were measured using the spectrophotometer (Beckman Coulter Korea, Seoul) at the wavelength of $600 \mathrm{~nm}$.

\section{GRE and SC solution preparation}

GR powder was obtained from GS Bio (Jeonju, Korea), isolated from plant material as described previously ${ }^{8)}$. Briefly, $1 \mathrm{~kg}$ of plant material was dried in an oven at $60^{\circ} \mathrm{C}$ for 3 days and extracted with ethanol twice at room temperature. The remaining residue was removed by filtration (Whatman no. 2, Sigma-Aldrich Korea, Yongin), and the filtrate was concentrated using a vacuum rotary evaporator (Iwai Co., Japan), followed by freezing of the dried powder. This crude, extracted powder was used in the present study.

$\mathrm{SC}$ was purchased from Sigma-Aldrich Korea (Yongin, Korea). To make $30 \mathrm{mM} \mathrm{SC}$ stock solution, $3.2 \mathrm{~g}$ of SC was dissolved in distilled water with a final volume of $1 \mathrm{~L}$. After the SC stock solution was suitably diluted with distilled water, the diluents were used in this study.

\section{Cytotoxicity assay}

To determine the cytotoxicity of GRE, SC and GS, RAW 264.7 cells $\left(1 \times 10^{5} \mathrm{cells} / \mathrm{mL}\right)$ were cultured in the presence of different concentrations of GRE $(0,50,100,200,300$, 400 and $500 \mu \mathrm{g} / \mathrm{mL}), \mathrm{SC}(0,1.5,3,6,9,12$ and $15 \mathrm{mM})$ and GS $(0,0.1,0.2,0.4,0.6,0.8$, and 1 (GRE $1,000 \mu \mathrm{g} / \mathrm{mL}+\mathrm{SC}$ $30 \mathrm{mM})$ ) in a 96-well cell culture plate for $48 \mathrm{hr}$. The cell viability was measured using a 3-(4,5-dimethylthiazol-2yl)2,5-diphenyl-2H-tetrazolium bromide (MTT) cleavage assay that is a sensitive analysis for cytotoxicity that is based on the detection of mitochondrial enzymatic activity that reacts with a chromogenic substrate ${ }^{23)}$. In brief, RAW 264.7 cells were inoculated in MTT solution $(5 \mathrm{mg} / \mathrm{mL}$ in PBS) and incubated at $37^{\circ} \mathrm{C}$ in $5 \% \mathrm{CO}_{2}$ for $4 \mathrm{hr}$. After incubation, plates were centrifuged at $450 \times \mathrm{g}$, and supernatants were removed. Acid/isopropanol (one portion of $4 \mathrm{~N} \mathrm{HCl}: 100$ portions of isopropanol) was added to the wells and mixed completely to dissolve crystalline material. Product generation is measured at an optical density (OD) of $570 \mathrm{~nm}$.

\section{Bactericidal analysis}

Bacteria grown to stationary phase were diluted with phosphate-buffered saline solution (PBS, pH 7.4) to a concentration of $2 \times 10^{4} / \mathrm{mL}$ and added to PBS containing different concentrations of GRE $(0,50,100,200$ and 400 $\mu \mathrm{g} / \mathrm{mL}), \mathrm{SC}(0,1.875,3.75,7.5$ and $15 \mathrm{mM})$ and $\mathrm{GS}(0,0.1$, $0.2,0.4$, and $0.8(1 ;$ GRE $1,000 \mu \mathrm{g} / \mathrm{mL}+\mathrm{SC} 30 \mathrm{mM})$ ), and 
incubated at $37^{\circ} \mathrm{C}$ for $0,1,4,8,16$, and $24 \mathrm{hr}$. After incubation and dilution, $100 \mu \mathrm{L}$ of each diluent was plated onto Brucella agar and cultured for 3 days at $37^{\circ} \mathrm{C}$ to determine bacterial colony forming units (CFUs).

\section{Inhibitory effects for intracellular proliferation of $B$. abortus}

For the inhibitory efficiency measurements, RAW 264.7 cells were infected with $B$. abortus according to the method by Lee et al. $(2004)^{8)}$. After infected cells were incubated at $37^{\circ} \mathrm{C}$ for $1 \mathrm{hr}$, cells were washed once with media and then incubated with RPMI 1640 media containing 10\% FBS with gentamicin $(30 \mu \mathrm{g} / \mathrm{mL})$ for $30 \mathrm{~min}$ to kill any remaining extracellular bacteria. Referred on the results of cytotoxicity assay, infected cells were treated with GRE $(400 \mu \mathrm{g} / \mathrm{mL})$, $\mathrm{SC}(15 \mathrm{mM})$ and $0.5 \mathrm{GS}$ (GRE $500 \mu \mathrm{g} / \mathrm{mL}+15 \mathrm{mM})$ and incubated for 2, 24 or $48 \mathrm{hr}$. To evaluate the number of viable bacteria at different periods of time, the infected cells were extensively washed three times with PBS and then lysed with distilled water. The number of viable bacteria was determined by counting the CFU from serial dilutions of cell lysates that were spread on Brucella agar plates in triplicate.

\section{Statistical analysis}

The data were expressed as the mean \pm standard deviation (SD) for the triplicate experiments. The significance between the control group and experimental groups was determined by Student's $t$-test. A difference at the level of $p<0.05$ was considered to be statistically significant.

\section{Results}

\section{Cytotoxic effects on murine macrophage}

Table 1 showed the cytotoxicity of GRE, SC and GS against RAW 264.7 cells. The cells were cultured in the presence of different concentrations of $\operatorname{GRE}(0,50,100,200$, $300,400$ and $500 \mu \mathrm{g} / \mathrm{mL})$, SC $(0,1.5,3,6,9,12$ and 15 $\mathrm{mM})$ and $\mathrm{GS}(0,0.1,0.2,0.4,0.6,0.8,1$ (GRE 1,000 $\mu \mathrm{g} / \mathrm{mL}$ + SC $30 \mathrm{mM}$ ) for $48 \mathrm{hr}$.

Cell viability was assessed by the MTT assay and correlated with OD values and the results of trypan blue exclusion assays. The OD values of the cultures treated with $500 \mu \mathrm{g} /$ $\mathrm{mL}$ of GRE and 0.8 and 1 of GS (GRE $1,000 \mu \mathrm{g} / \mathrm{mL}+\mathrm{SC}$ $1.6 \mathrm{mg} / \mathrm{ml}$ ) were significantly lower than those treated with $0 \mu \mathrm{g} / \mathrm{mL}$ of GRE and 0 of GS, respectively $(p<0.05)$, but there was no significant difference between those treated

Table 1. The cytotoxicity of GRE, SC and GS against RAW 264.7 cells by MTT assay

\begin{tabular}{cccccc}
\hline & \multicolumn{3}{c}{ GRE } & \multicolumn{2}{c}{ GS } \\
\hline Con. $(\mu \mathrm{g} / \mathrm{ml})^{1)}$ & OD $^{2)}$ & Con. $(\mathrm{mM})$ & OD & Con. & OD \\
\hline 0 & $1.46 \pm 0.14$ & 0 & $1.41 \pm 0.15$ & 0 & $1.45 \pm 0.14$ \\
50 & $1.54 \pm 0.18$ & 1.5 & $1.56 \pm 0.17$ & 0.1 & $1.53 \pm 0.25$ \\
100 & $1.42 \pm 0.13$ & 3 & $1.35 \pm 0.14$ & 0.2 & $1.44 \pm 0.15$ \\
200 & $1.45 \pm 0.15$ & 6 & $1.40 \pm 0.15$ & 0.4 & $1.39 \pm 0.13$ \\
300 & $1.38 \pm 0.14$ & 9 & $1.33 \pm 0.13$ & 0.6 & $1.35 \pm 0.15$ \\
400 & $1.25 \pm 0.17$ & 12 & $1.27 \pm 0.14$ & 0.8 & $1.23 \pm 0.11^{*}$ \\
500 & $1.17 \pm 0.12^{*}$ & 15 & $1.20 \pm 0.15$ & $1^{3)}$ & $1.15 \pm 0.12^{*}$ \\
\hline
\end{tabular}

${ }^{1)}$ Con. : concentration.

${ }^{2)}$ Optical density (OD) values are presented as the mean \pm standard deviation of the mean.

${ }^{3)}$ The concentration of GS (GRE $1,000 \mu \mathrm{g} / \mathrm{ml}+\mathrm{SC} 30 \mathrm{mM}$ ) was represented as 1 .

${ }^{*} p<0.05$, significant difference as compared with the respective value of untreated cells.
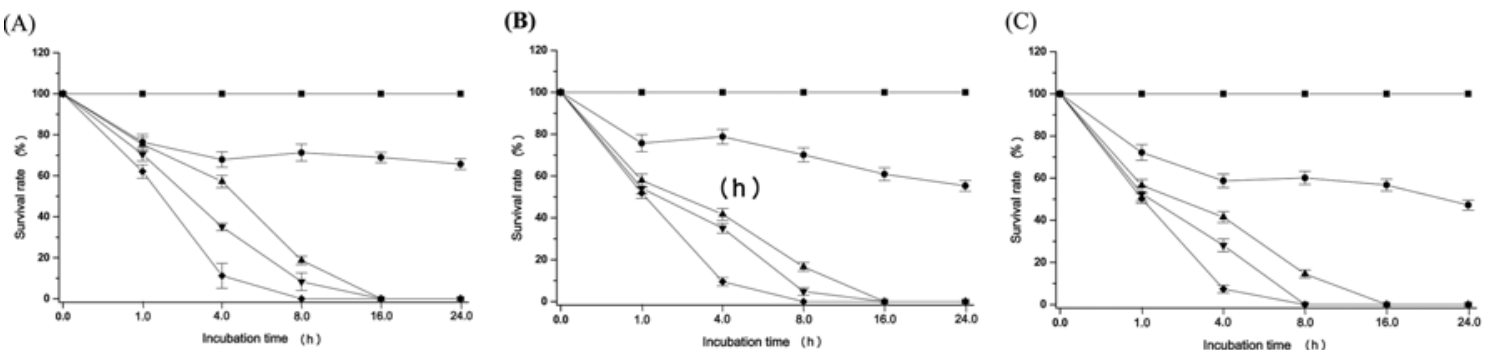

Fig. 1. Bactericidal effects of GRE, SC and GS on Brucella abortus. Different concentrations of (A) GRE (0 ( $\mathbf{\square}), 50$ ( $(\mathbf{O}), 100$ ( $\mathbf{\Delta}), 200$ ( $\boldsymbol{\nabla})$ and $400(\boldsymbol{\nabla}) \mu \mathrm{g} / \mathrm{mL}),(\mathrm{B}) \mathrm{SC}(0(\boldsymbol{\square}), 1.875(\boldsymbol{\bullet}), 3.75(\boldsymbol{\Delta}), 7.5(\boldsymbol{\nabla})$ and $15(\boldsymbol{\nabla}) \mathrm{mM})$ and $(\mathrm{C}) \mathrm{GS}(0(\boldsymbol{\square}), 0.1(\boldsymbol{\bullet}), 0.2(\boldsymbol{\Delta}), 0.4(\boldsymbol{\nabla})$, and $0.8(\boldsymbol{\nabla})$ (1; GRE $1,000 \mu \mathrm{g} / \mathrm{mL}+\mathrm{SC} 30 \mathrm{mM})$ ) were diluted in PBS and incubated with B. abortus for 1, 4, 8, 16 and 24 hr. Bacterial viability was monitored by measuring CFUs on culture plates, and the rate of bacterial viability was compared to the zero time point in the untreated PBS. The data represent the mean \pm S.D. of triplicate experiments. 
with $15 \mathrm{mM}$ of SC and $0 \mathrm{mM}$ of SC. These data indicated that GRE, SC and GS are not cytotoxic at concentrations less than $400 \mu \mathrm{g} / \mathrm{ml}, 15 \mathrm{mM}$ and $0.6 \mathrm{GS}$ ( 1 of GS, GRE $1,000 \mu \mathrm{g} / \mathrm{ml}+\mathrm{SC} 30 \mathrm{mM})$, respectively.

\section{Bactericidal effects of GRE and GS on B. abortus}

Fig. 1 presented the bactericidal effect of GRE, SC and GS on $B$. abortus. The bacteria were incubated with different concentrations of GRE $(0,50,100,200$ and $400 \mu \mathrm{g} / \mathrm{mL})$, SC $(0,1.875,3.75,7.5$ and $15 \mathrm{mM})$ and $\mathrm{GS}(0,0.1,0.2,0.4$, and 0.8 (1; GRE $1,000 \mu \mathrm{g} / \mathrm{mL}+\mathrm{SC} 30 \mathrm{mM})$ ) in PBS at $37^{\circ} \mathrm{C}$ for $0,1,4,8,16$, or $24 \mathrm{hr}$.

Bacterial survival rates were calculated by counting CFUs and expressed as a percentage of the survival rate of the treated sample relative to an untreated control $(0 \mu \mathrm{g} / \mathrm{mL})$, which was set to $100 \%$. Bacterial survival rates were markedly decreased in a dose-dependent manner in all treatment groups (Fig. 1A, GRE; Fig. 1B, SC; Fig. 1C, GS) (Fig. 1). In all concentrations except for the lowest dose in all groups, the survival of bacteria treated with drugs showed rapid decreases with increasing incubation time.

\section{Inhibitory effects of GRE, SC and GS on bacterial intracellular proliferation}

To determine whether GRE, SC and GS inhibit the replication of $B$. abortus in macrophages, RAW 264.7 cells were treated with GRE $(400 \mu \mathrm{g} / \mathrm{mL}), \mathrm{SC}(15 \mathrm{mM})$ and $0.5 \mathrm{GS}$ (GRE $500 \mu \mathrm{g} / \mathrm{mL}+\mathrm{SC} 15 \mathrm{mM}$ ) using the same conditions as those used for the cytotoxicity assay, and incubated for

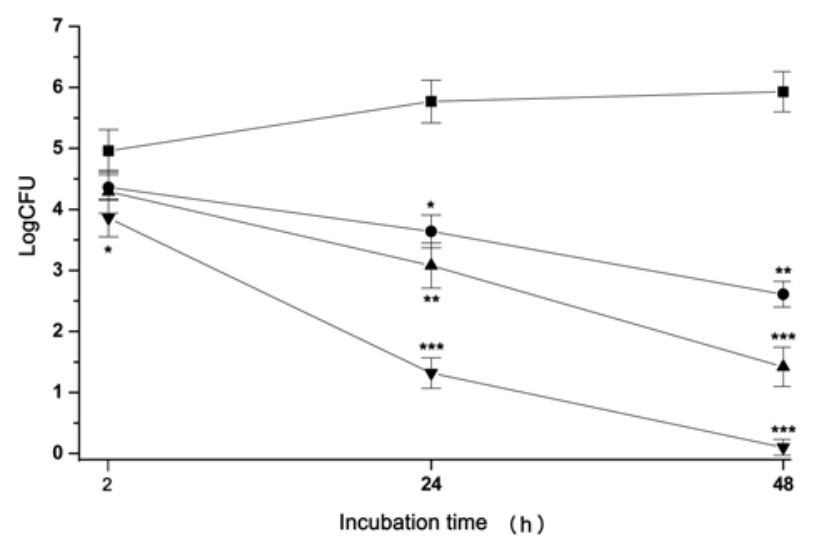

Fig. 2. Effects of GRE, SC and GS on the intracellular replication of Brucella abortus. RAW 264.7 macrophages were infected with B. abortus at MOIs of 10 , and the infected cells were incubated with saline ( $\mathbf{\square})$, GRE $400 \mu \mathrm{g} / \mathrm{mL}(\mathbf{O})$, SC $15 \mathrm{mM}(\boldsymbol{\Delta})$ and $0.5 \mathrm{GS}$ $(1$; GRE $1,000 \mu \mathrm{g} / \mathrm{mL}+\mathrm{SC} 30 \mathrm{mM})(\boldsymbol{\nabla})$ for 2,24 and $48 \mathrm{hr}$. Intracellular growth efficiency was evaluated by $\log _{10} \mathrm{CFU}$. Data are the averages of triplicate samples from three identical experiments, and the error bars represent the standard deviations. Statistically significant differences relative to the untreated control sample are indicated by asterisks $\left({ }^{*} p<0.05 ;{ }^{* *} p<0.01 ;{ }^{* * *} p<0.001\right)$.
2, 24 and $48 \mathrm{hr}$ after B. abortus infection (Fig. 2).

At $24 \mathrm{hr}$ post-treatment, the intracellular replication of $B$. abortus in GRE, SC and GS was significantly inhibited as compared to that of the untreated control (GRE, $p<0.01$; SC and GS, $p<0.001)$. At $48 \mathrm{hr}$ post-treatment, B. abortus intracellular replication in GRE, SC and GS was significantly prohibited as compared to that of the untreated control (GRE, $p<0.01$; SC and GS, $p<0.001)$. These results indicate that GRE, SC and GS have an inhibitory activity for the proliferation of $B$. abortus in murine macrophages.

\section{Discussion}

Brucellosis is one of the recognized zoonoses and is considered by the Food and Agricultural Organization (FAO), WHO and the Office International des Epizooties (OIE) as the most widespread zoonosis globally ${ }^{24)}$. Vaccination has been used for the control of brucellosis. However, there is currently no safe or efficient vaccine that can be used to control human brucellosis ${ }^{25)}$, and treatment for brucellosis with antibiotics also remains controversial and requires prolonged therapy with at least two agents ${ }^{26}$. In addition, Brucella has developed various strategies to evade innate and adaptive host immune responses, aimed at establishment of an intracellular niche for long-term survival and replication ${ }^{27}$. These facts may indicate that the conventional antibiotic regimen is not suitable for brucellosis treatment, and together with the rapid emergence of antibiotic resistance and the delayed use of antibiotics, could lead to serious problems. Furthermore, there have been few reports examining the use of traditional plants and non-residualchemical compounds for the treatment of brucellosis. Therefore, conventional treatments for brucellosis should be increasingly regulated, and alternative, sophisticated treatments that abrogate the invasion and intracellular trafficking of Brucella need to be identified.

GR possesses positive health benefits, including anti-tumorigenic, anti-oxidative, anti-inflammatory and anti-microbial properties and GRE in the previous study significantly inhibits the growth of intracellular pathogenic bacteria such as Clostridium perfringens ${ }^{16,28,29}$. Additionally, many previous studies reported that SC had a bactericidal activity against Enterobacteriaceae because of the chlorite from which the chlorate is reduced by a respiratory nitrate reductase ${ }^{19-22}$.

In the previous study ${ }^{8}$, the cytotoxic effect of GRE was not detected at the concentrations between 0 and $400 \mu \mathrm{g} / \mathrm{mL}$ by trypan blue exclusion assays. In this study, GRE at the doses of below $400 \mu \mathrm{g} / \mathrm{mL}$ was occurred non-toxic to cells same with the above study. In addition, Lee et al. (2012) ${ }^{30)}$ reported that the survival rate of $B$. abortus in pure culture was reduced to $0 \%$ at $8 \mathrm{hr}$ post-incubation by Phellinus 
baumii ethanol extracts (PBE) at the concentration of 400 $\mu \mathrm{g} / \mathrm{mL}$. Furthermore, Lee et al. $(2011)^{8)}$ reported that the survival rate of $B$. abortus was markedly decreased into $0 \%$ at $8 \mathrm{hr}$ post-incubation with the dose of GRE $400 \mu \mathrm{g} / \mathrm{mL}$. In the present study, GRE, SC and GS reduced the survival rates of $B$. abortus into $0 \%$ at $8 \mathrm{hr}$ post-incubation with the dose of $500 \mu \mathrm{g} / \mathrm{mL}, 15 \mathrm{mM}$ and $0.8 \mathrm{GS}$, respectively. Compared to the above results, antibacterial effect of SC and GS on B. abortus was similar with that of PBE and GRE. Meanwhile, infected-macrophage cells treated with PBE 100 $\mu \mathrm{g} / \mathrm{mL}$ and GSE $200 \mu \mathrm{g} / \mathrm{mL}$ in the previous studies displayed the reduction of intracellular proliferation rate of $B$. abortus into more than $99 \%$ compared to the untreated-control. On the other hand, 0.5GS-treated cells in this study reduced the intracellular proliferation rate of B. abortus into about $0 \%$. With the consideration of the treated-dosage, the antibacterial effect of GS on B. abortus might be higher than that of PBE and GRE.

The previous study reported that the tannin components of GRE directly inhibit the growth of intracellular replication in macrophages ${ }^{8)}$. In addition, chlorate from SC is reduced into chlorite, a cytotoxic product by the respiratory nitrate reductase that $B$. abortus such as obligatory intracellular bacteria has a reductase enzyme for the nitrogen fixation within cells ${ }^{21,22)}$. Therefore, a strong synergistic antibacterial effect in GS was observed against B. abortus with the associations between the tannin components of GRE and chlorate derived from SC. Then GS was useful as an antibacterial candidate against B. abortus.

In conclusion, this study emphasizes the idea that GS has an antibacterial effect against $B$. abortus, and possibly other intracellular pathogenic bacteria. In the future, it will be necessary to determine the antibacterial usefulness of GS in the application of foods such as milk, dairy products and meat from animals infected with $B$. abortus.

\section{Acknowledgements}

This research was supported by the Basic Science Research Program through the National Research Foundation of Korea (NRF), funded by the Ministry of Education, Science and Technology (Grant No. 2010-0021247).

\section{요 약}

본 연구는 오배자 에탄올 추출물 (GRE), 염소산나트륨 (SC) 그리고 오배자 에탄올 추출물과 염소산나트륨 합제 (GS)의 B. abortus에 대한 항균효과를 확인하기 위해 수행 되었다. GRE, $\mathrm{SC}$ 그리고 $\mathrm{GS}$ 를 B. abortus에 처리하여 배 양한 후, B. abortus의 생존수를 확인하였으며, 마우스 탐 식세포 내 감염된 B. abortus의 증식 억제효과를 경시별 (2,
24,48 시간)로 조사하였다. $\mathrm{GRE}, \mathrm{SC}$ 그리고 $\mathrm{GS}$ 는 각각 $400 \mu \mathrm{g} / \mathrm{mL}$ 이하, $15 \mathrm{mM}$ 그리고 $0.6 \mathrm{GS}$ (GS 1, GRE 1,000 $\mu \mathrm{g} / \mathrm{mL}+\mathrm{SC} 30 \mathrm{mM}$ ) 이하의 농도에서 세포독성을 나타나 지 않았다. 모든 처리구에서 B. abortus의 생존율은 용량의존적으로 현저하게 감소하는 결과를 나타내었다. 또한, $\mathrm{GRE}(400 \mu \mathrm{g} / \mathrm{mL}), \mathrm{SC}(15 \mathrm{mM})$ 그리고 $0.5 \mathrm{GS}$ (GRE 500 $\mu \mathrm{g} / \mathrm{mL}+\mathrm{SC} 15 \mathrm{mM}$ )를 처리한 세포에서 배양 48시간 후 에, B. abortus의 증식이 통계적으로 유의성 있게 감소하 였으며 (GRE, $p<0.01$; SC and $0.5 \mathrm{GS}, p<0.001$ ), 특히, $\mathrm{GS}$ 를 처리한 경우, B. abortus의 세포내 증식이 GRE와 $\mathrm{SC}$ 의 상승작용에 의한 강력한 항균효과를 나타내었다. 결 론적으로, $\mathrm{GS}$ 는 B. abortus에 대한 항균물질로서 유용할 뿐만 아니라, 식육과 우유 위생 분야에 적용할 수 있을 것 으로 생각된다.

\section{References}

1. Lopes, L. B., Nicolino, R. and Haddad, J. P. A. Brucellosis risk factors and prevalence: A review. Open Vet. Sci. J., 4, 7284, 2010.

2. Trujillo, I.Z., Zavala, A.N., Caceres, J.G. and Miranda, C.Q.: Brucellosis. Infect. Dis. Clin. North Am. 8, 225-241 (1994).

3. Corbel, M.J.: Brucellosis: an overview. Emerg. Infect. Dis. 3, 213-221 (1977).

4. Atluri, V.L., Xavier, M.N., Jong, M.F., Hartigh, A.B. and Tsolis, R.M.: Interactions of the human pathogenic Brucella species with their hosts. Annu. Rev. Microbiol. 65, 523-541 (2011).

5. Díaz Aparicio, E.: Epidemiology of brucellosis in domestic animals caused by Brucella melitensis, Brucella suis and Brucella abortus. Rev. Sci. Tech. Off. Int. Epiz., 32, 53-60 (2013).

6. Namanda, A.T., Kakai, R. and Otsyula, M.: The role of unpasteurized "hawked" milk in the transmission of brucellosis in Eldoret municipality, Kenya. J. Infect. Dev. Ctries. 3, 260-266 (2009).

7. World Health Organization (WHO): Brucellosis in humans and animals. WHO press, Geneva, pp. 50-52 (2006).

8. Lee, J.J., Bae, J.H., Kim, D.H., Lim, J.J., Kim, D.G., Lee, H.J., Min, W., Rhee, M.H., Chang, H.H., Park, H. and Kim, S.: Intracellular replication inhibitory effects of Galla Rhois ethanol extract for Brucella abortus infection. J. Ethnopharmacol. 138, 602-609 (2011).

9. Liautard, J.P., Gross, A., Dornand, J., Kohler, S.: Interactions between professional phagocytes and Brucella spp. Microbiol. 12, 197-206 (1996).

10. Ariza, J., Bosilkovski, M., Cascio, A., Colmenero, J.D., Corbel, M.J., Falagas, M.E., Memish, Z.A., Roushan, M.R., Rubinstein, E., Sipsas, N.V., Solera, J., Young, E.J. and Pappas, G.: Perspectives for the treatment of brucellosis in the 21st century: the Ioannina recommendations. PLoS Med. 4, e317 (2007).

11. Skalsky, K., Yahav, D., Bishara, J., Pitlik, S., Leibovici, L. and Paul, M.: Treatment of human brucellosis: systematic 
72 Chun-Nam Cha, Il-Hwa Hong, Eun-Ah Yu, Eun-Kee Park, Chang-Yeol Yoo, Suk Kim, and Hu Jang Lee

review and meta-analysis of randomised controlled trials. $B r$. Med. J. 336, 701-704 (2008).

12. Yousefi-Nooraie, R., Mortaz-Hejri, S., Mehrani, M. and Sadeghipour, P.: Antibiotics for treating human brucellosis. Cochrane Database Syst. Rev. 10, CD007179 (2012).

13. Cha, C.N., Yu, E.A., Park, E.K., Choi, H., Kim, S. and Lee, H.J.: Antibacterial effects of Galla Rhois extract against Streptococcus suis infection in mice. J. Fd. Hyg. Safety, 28, 95-98 (2013).

14. Lee, J.J., Kim, D.H., Lim, J.J., Kim, D.G., Min, W., Kim, G.S., Lee, H.J., Rhee, M.H., Park, H., Kim, S.C., Chang, H.H. and Kim, S.: Anticoccidial effect of supplemental dietary Galla Rhois against infection with Eimeria tenella in chickens. Avian Pathol. 41, 403-407 (2012).

15. Djakpo, O. and Yao, W.: Rhus chinensis and Galla Chinensis - folklore to modern evidence: review. Phytother. Res. 24, 1739-1747 (2010).

16. Ahn, Y.J., Lee, H.S., Oh, H.S., Kim, H.T. and Lee, Y.H.: Antifungal activity and mode of action of Galla Rhois-derived phenolics against phytopathogenic fungi. Pestic. Biochem. Phys. 81, 105-112 (2005).

17. Chen, J.C., Ho, T.Y., Chang, Y.S., Wu, S.L. and Hsiang, C.Y.: Antidiarrheal effect of Galla Chinensis on the Escherichia coli heat-labile enterotoxin and ganglioside interaction. $J$. Ethnopharmacol. 103, 385-391 (2006).

18. National Toxicology Program (NTP): The toxicology and carcinogenesis studies of sodium chlorate (CAS No. 777-099) in $\mathrm{F} 33 / \mathrm{N}$ rats and $\mathrm{B} 6 \mathrm{C} 3 \mathrm{~F}_{1}$ mice (Drinking water studies). National Institute Health (NIH), Bethesda, pp. 5-6 (2005).

19. Anderson, R.C., Buckley, S.A., Kubena, L.F., Stanker, L.H., Harvey, R.B. and Nisbet, D.J.: Bactericidal effect of sodium chlorate on Escherichia coli O157:H7 and Salmonella Typhimurium DT104 in rumen contents in vitro. J. Food Prot. 63, 1038-1042 (2000).

20. Anderson, R.C., Harvey, R.B., Byrd, J.A., Callaway, T.R., Genovese, K.J., Edrington, T.S., Jung, Y.S., McReynolds, J.L. and Nisbet, D.J.: Novel preharvest strategies involving the use of experimental chlorate preparations and nitro-based compounds to prevent colonization of food-producing animals by foodborne pathogens. Poult. Sci. 84, 649-654 (2005).
21. Anderson RC, Hume ME, Genovese KJ, Callaway TR, Jung YS, Edrington TS, Poole TL, Harvey RB, Bischoff KM, Nisbet DJ. Effect of drinking water administration of experimental chlorate ion reparations on Salmonella enteric serovar Typhimurium colonization in weaned and finished pigs. Vet. Res. Commun. 28, 179-189 (2004).

22. BioModels Database: Nitrogen metabolism - Brucella abortus (strain 2308). EMBL-EBI, Hinxton, UK, http://www.ebi.ac. uk/biomodels-main/BMID000000106272 (2013).

23. Mosmann, T.: Rapid colorimetric assay for cellular growth and survival: application to proliferation and cytotoxicity assays. J. Immunol. Methods, 65, 55-63 (1983).

24. Bosilkovski, M., Krteva, L., Dimzova, M. and Kondova, I.: Brucellosis in 418 patients from the Balkan Peninsula: exposure-related differences in clinical manifestations, laboratory test results, and therapy outcome. Int. J. Infect. Dis. 11, 342347 (2007).

25. Young, E.J.: Brucella species. In Mandell, Douglas and Bennet's Principles and Practice of Infectious Disease, 5th Ed. (Mandell, G.L., Bennett, J.E. and Dolin, R. eds.) Churchill Livingstone, Philadelphia, pp. 2386-2393 (2000).

26. Prior, S., Gander, B., Lecároz, C., Irache, J.M. and Gamazo, C.: Gentamicin-loaded microspheres for reducing the intracellular Brucella abortus load in infected monocytes. J. Antimicrob. Chemother. 53, 981-988 (2004).

27. Skendros, P. and Boura, P.: Immunity to brucellosis. Rev. Sci. Tech. 32, 137-147 (2013).

28. Cai, Y., Luo, Q., Sun, M. and Corke, H.: Antioxidant activity and phenolic compounds of 112 traditional Chinese medicinal plants associated with anticancer. Life Sci. 74, 2157-2184 (2004).

29. Kratz, J.M., Andrighetti-Frohner, C.R., Leal, P.C., Nunes, R.J., Yunes, R.A., Trybala, E., Berqstrom, T., Barardi, C.R. and Simoes, C.M.: Evaluation of anti-HSV-2 activity of gallic acid and pentyl gallate. Biol. Pharm. Bull.31, 903-907 (2008).

30. Lee, J.J., Kim, D.H., Kim, D.G., Lee, H.J., Min, W., Rhee, M.H., Yun, B.S. and Kim, S.: Phellinus baumii extract influences pathogenesis of Brucella abortus in phagocyte by disrupting the phagocytic and intracellular trafficking pathway. J. Appl. Microbiol. 114, 329-338 (2012). 